\title{
اتجاهات الطلاب المعلمين نحو برنامج التربية الميدانية بكلية العلوم والآداب بشرورة وعلاقتها ببعض المتفيرات
}

\author{
د. محمد بن هادي الشهري \\ كلية العلوم والآداب بشرورة - جامعة نجران - المملكة العربية السعودية
}

تاريخ القبول: 2018/2/28

تاريخ الورود : 2017/18 / 18

الملخص

هدفت الدراسة الحالية إلى تعرف اتجاهـات الطلاب المعلميـن بكلية العلوم والآداب بهحافظة شرورة نحو برنامج التربية الميدانية، وعلاقتها ببعض المتفيرات (الجنس، التخصص، التقدير). ولتحقيق ذلك استخدم الباحث المنهج التحليلي الوصفي، وتم تصميم مقياس الاتجاهات نحو برنامج التربية الميدانية، والذي تكون من (20) فقرة، وطبقت على عينة الدراسـة البالغ عددها

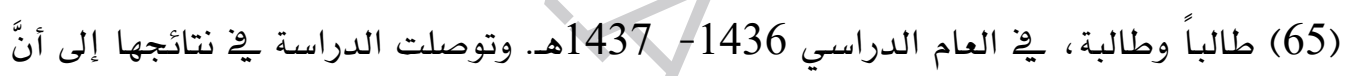
الاتجاه العام للطالبات والطلاب المعلمين نحو برنامج التربية الميدانية جاء إيجابياً ، وبدرجة مرتقعة. كما تبين عدم وجود فروق داله تعزى لاختلاف متفيري الجنس، والتقدير، بينما وجدت فروق دالة إحصائياً تعزى لاختلاف متغير التخصص لصالح تخصص الدراسات الإسـلامية. وأوصت الدراسة بالاهتمام باتجاهـات الطالبات والطلاب المعلمـين نحو التربية الميدانية، والعهل على تحسينها ، وبناء اتجاهات إيجابية نحو نشاطاتها، وممارساتها ، والاستعانة بهعطيات العصر، ووسائل التواصل وِّ مجال التربية الميدانية لتطوير برامجها ، والعهل على توسيع مجالات، ووسـائل الحوار، والنقاش، والتدريب، والتفاعل، والتواصل وخ التربية الميدانية، وإشراك كل الأطراف

المعنية ِِّ ذلك، مع توسيع دورها و مجالات مشاركتها. الكلمات المفتاحية: إعداد المعلمين، التربية الميدانية، الطلاب المعلمون. 


\title{
The Attitudes of Teachers Students in the Faculty of Science and Arts at Sharourah Governorate Towards Teaching Practice Program and its Relationship with some Variables
}

\author{
By \\ Dr. Mohammed bin Hadi al-Shihri \\ Faculty of Arts and Sciences - Najran University - Saudi Arabia
}

\begin{abstract}
This study aimed to identify the attitudes of teacher's students in the Faculty of Science and Arts at sharourah Governorate towards teaching practice program, and its relationship with some variables (gender, major, grade). To achieve this, the researcher used the analytical descriptive method, and then the attitude scale was designed towards the teaching practice program that consists of 20 items, applied the sample of the study consisting of (65) students. The results of study showed that the general attitude towards the teaching practice program was positive and got high degree. There were no significant differences in teachers students' attitudes due to gender and grade variable, There were significant differences due to major variable in favor of Islamic Studies major. The researcher recommended to concern with teacher student towards teaching practice program and to improve it to build positive attitudes towards its activities and practices.
\end{abstract}

Keywords: Teacherspreparation, Teaching practice program, Teachers students. 
مقلدمة

كل يوم تترستخ القناعة بأن المُخرج المتميز من الطلاب، المتمكن من مهارات الحياة، القادر على النجاح ـوْ وظيفته المستقبلية - يتطلب معلماً متهكناً يْ مهنته، معلماً يفتح الباب لطلابه للنهل من العلم، ويكتشف ما لديهم من مواهب، وقدرات، وييسر لهم تتمية المهارات، واكتساب الخبرات.

فعلى الرغم مها شهده العصر الحاضر من تقدم پِّ المعرفة، والتكنولوجيا ، وكافة عناصر المنهج، ومكوناته - فقد حافظ المعلم على دوره مهثلاً عصب العهلية التعليمية، والركيزة الأساسية يخّ تحقيق أهدافها؛ وقد أدى كل ذلك إلى تضاعف التحديات أمام المعنيين ِِّ برامج إعداد المعلمين، ليقدموا مخرجات من معلمين متمكنين يخ تخصصاتهم، يمتلكون خبرات

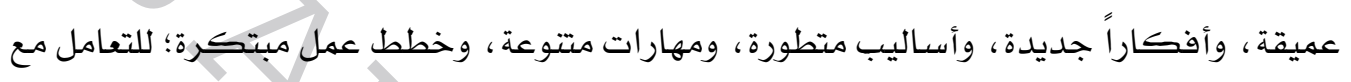
متطلبات هذا الواقع المتطو، والبيئة التربوية المتفيرة بإبداع متجدد. ووِخ هذا الإطار تشير الوكالة القومية للتدريس بالولايات المتحدة إلى أن التحديات الموجودة اليوم يخ المدارس تتطلب أن يعد المعلمون أفضل من ذي قبل؛ لأنَّ معلمي القرن الواحد والعشرين،

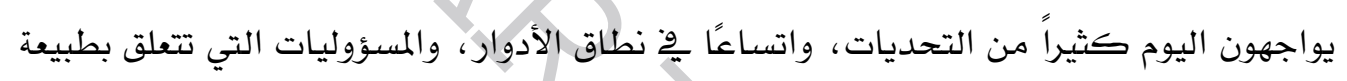
الأجيال الجديدة. (الأدغم، 2003م).

ونتيجة لما تقدم فقد أولت كافة الدول اهتهاماً بكليات إعداد المعلمين، واعتتت بتطوير برامج إعدادهم، وتدريبهم أثناء الخدمة؛ لتأدية مهامهم مِّ ضوء التطورات الحديثة، ووفقاً للتوجهات العالمية المعاصرة، ويشهل ذلك إعدادهم ِِّ مجالات التخصص، ومهنة التدريس، والمهارات المطلوبة لذلك، إضافة إلى إعداد شخصية المعله العلمية، والثقافية، والاجتماعية المتكاملة؛ بما يساعده على القيام بدوره يْ تطوير، وإصلاح مخرجات التعليه. وتأتي التربية الميدانية ِِّ مقدمة مكونات برامج إعداد المعلمـين التي تحظى بالاهتهام ومحاولات التطوير? فهي بهثابة الجسر الذي يعبر من خلاله الطالب المعلم إلى ميدان العمل، مطبقاً من خلاله ما اكتسبه وِّ الكلية من المعلومات النظرية، والمبادئ التربوية، ومهارساً لها على أرض الواقع ِِّ مدرسة التدريب، وذلك بالتعاون، والدعم من قائدها ، والمعله المتعاون فيها ، وغيره من المعلهـين، وبإشـراف مباشر من مشرف خبير، وتعاون، وتقاعل، وتبادل للأفكار،

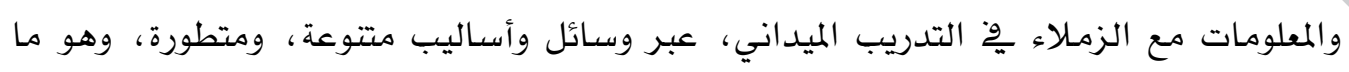
يهكنه من المهارسة السليمة، والتطبيق الواعي لما تم تعلمها من معلومات، ويمنحه الفرصة 
لاكتساب المهارات، والتقويم، والتطوير، والثقة بالنفس، والمسـاعدة على اتخاذ القرارات

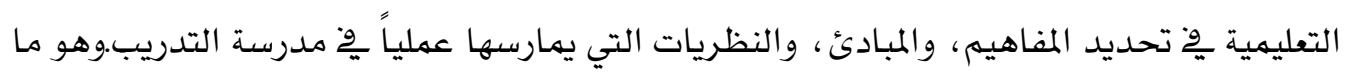
يؤكده أرورا (Arora, 2006) الذي يذهب إلى أنَّ التربية الميدانية هي المكون الرئيس لبرنامج الإعداد، وهي تهدف إلى إعداد الطلاب ليكونوا معلمين ناجحين بالاعتماد على أدوار ومواقف الموجهين، والإداريين، والمدربين، والمعلمـين المتعاونين. ويذهب سـرفرد (Srafard,1995) إلى أنّها تمثل قهمة الخبرة ، والنشاط يخ الإعداد المهني للمعلمـين قبل الخدمة. أما أبو لبدة، والخليلي، وأبو زينة (1996م) فيذهبون إلى أن التربية الميدانية فرصة أمام الطلاب المعلمـين لوضع ما اكتسبوه من معارف، ونظريات، ومهارات، واتجاهات موضع التتفيذ تحت إشراف متخصص، يكفل لهم تغذية راجعة مناسبة، تساعدهم على تعديل سلوكهم التعليهي وتطويره، كما يشير حمص، وعلي (1419هـ) إلى أن التربية الميدانية تعمل على تقريب الطالب المعلم من المهنة بشكل عملي فعال، ويصبح من خلالها جزءاً من حياة المجتهـع، والمدرسـة. ويكتسبـ بـذلك فهمـاً عميقـاً لعمليـة التعليم، والتعلم، والتعـرف على مشـكـلات التعليم الحقيقيـة، ويؤكــد تثـانج أون، وويـن واه (Cheung-On \& Yin-Wah, 2001) أن التربيـة

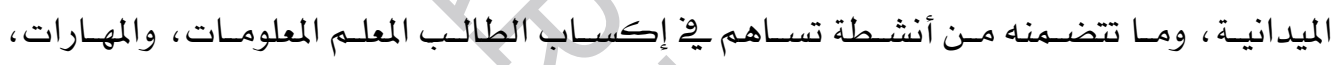

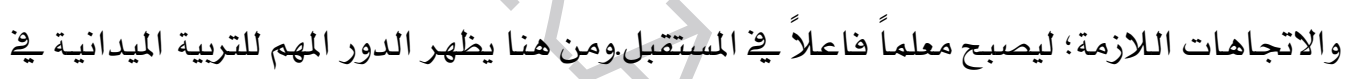
تثبيت الأسس النظرية التي درسها الطالب المعله أثناء فترة الإعداد، وربطها بـالواقع، كهـا تعرفه بالمواقف التعليمية ، وسبل التعامل معها ، وتسـاهم مو إيجـاد ، وتحسـين الاتجـاهـات الإيجابيـة لديـه

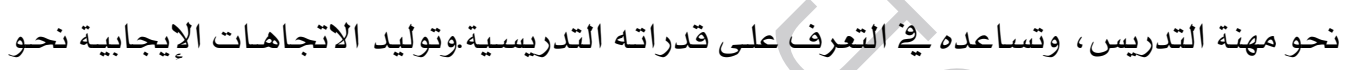

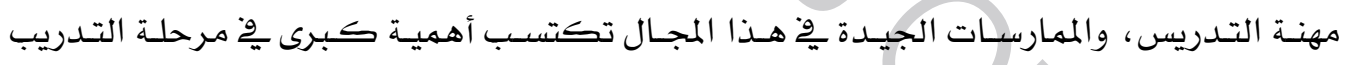

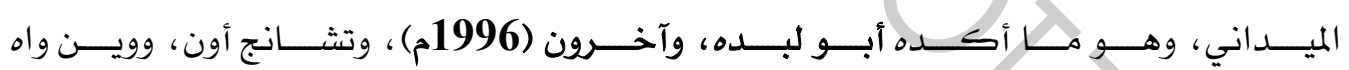

\section{.(Cheung-On \& Yin-Wah,2001)}

كما تبرز مِ2 هذا السياق دراسة كلير مسعود (2001م) اتقاق العديد من الدراسـات، والتجارب على الدور الحاسم للاتجاهات قِّ عملية التعلم، وتشير نصر الله (1988) إلى أهمية ذلك، باعتبار تتمية الاتجاهـات الإيجابية يخ العملية التعليمية تؤثر على مستوى، ومعدل اكتساب الفرد للمادة المتعلمة؛ مها ينعكس على مخرجات العملية التعليمية. وقد بدأ الاهتمام بدراسة الاتجاهات بعد ظهور مفهوم الاتجاه يخّ بداية القرن الحالي، إلا أن هذا الاهتمام قد زاد، وتطور بشكل خاص خلال الآونة الأخيرة، وأصبح تتمية الاتجاهات 
المرغوب فيها هدفاً أساسياً، ومهماً من أهداف التربية، وِّ مختلف المجالات العلمية والعملية. (ناصر ، 1999)

وتشكل الاتجاهات جزءاً مهماً من حياة الفرد، وذلك من خلال دورها مِّ عملية توجيه السلوك ِوْ كثير من مواقف الحياة، حيث تعمل على تسهيل استجابات الفرد ِِّ المواقف التي

لديه اتجاهات خاصة نحوها (عيسوي، 1981)

وتعتبر الاتجاهات من مكونات شخصية المعلم، حيث إنها تثكل مكوناً واقعيا يوجه، وينشط سلوك المعلم پِ المواقف التربوية التي تتطلب منه القبول، أو الرفض، والحب، أو الكراهية (عبد الرحهن وقطامي، 1992). والاتجاه مكتسب، فهو أمر يتعلمه الإنسان قو تتشئته الاجتماعية بها تشمله من خبرات، ومواقف يهر بها ، والأثر الأكبر وِّ تكوين الاتجاهات يعود إلى البيئة ، وتقاعل الفرد معها. وبها أن الاتجاه مكتسب يتعلمـه الفرد نتيجة خبرات يهر بها ، فهو قابل للتعديل، والتغيير. (جامعة القدس المفتوحة ، 1998) وبناء الاتجاهات الإيجابية لدى الطلاب المعلمين، وجعلهم يقبلون على مهنة التعليم، ويهارسون نشاطاتها بفاعلية خلال التربية الميدانية يتطلب تعاوناً من الأطراف المعنية بهذا المجال لتحقيق الدعم اللازم لتتمية تلك الممارسات، والوصول لأعلى درجات التفاعل، وقد توصلت دراسـة بيك (Beck, 2002) إلى أنَّنوع الدعم، والتفذية الراجعة المطلوبة التي يحتاج إليها الطالب المعلم، وآليات تزويده بها تتهثل وِّ توفير الدعم المعنوي من قبل المثرفين، والأقران، ودرجة التعاون مع زمائه المعلمـين المتعاونين، إضـافة إلى المرونة يخ المحتوى التعليهي، وطرق التدريس، ودور التغذية الراجعة التي يتلقونها ، وأثرها على إنجازهم، وكيفية تقديهها بطرق إنسانية، وأخلاقية، وعملية. ويشير الشهري (2012) إلى أنَّ بناء الاتجاهات، وتغييرها قد يرتبط بالفرد ذاته، ومدىى لته تقبله، وما يتمتع به من خبرات، وانفتاح على الآخرين، وتقبله للرأي الآخر، وقد يرتبط بهوضوع الاتجاه، ومدى حداثته، وقابليته للجذب، والتأثير يخ الفرد ، واستحواذه على اهتماماته، كما أنه قد يعتمد على الوسط الذي يعيش فيه الفرد ، والبيئة التي يقيم فيها وومن أنواع الدعم المناسبة خلق

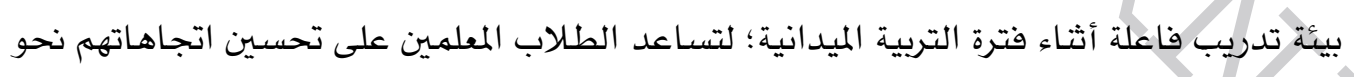

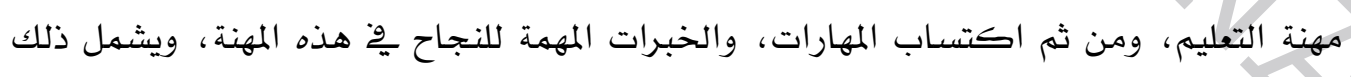
حسن اختيار نوعية مؤهلة من المشرفين، ومدراس مناسبة للتعليم، والتدرب عليه، وتطوير التواصل، والتفاعل، وتبادل الخبرات بين الطلاب المعلهـين أنفسهم، ومع مشرفيهم، وقادة 
المدراس، والمعلمـين المتعاونين، وسـائر الطاقم التدريسي، والإداري ِخ المدرسـة؛ مها يؤدي لاكتسـاب خبرات، ومهارات التدريس، وتحسين الاتجاهـات نحوه.

ويرى خوالده واحميدة والحجازي (2010) أن خلق هذه البيئة الفاعلة يجعل التربية الميدانية المحور الأهم، والأشمل لمهام الطالب المعلم ِِّ الميدان التربوي من أداء، وههارات، وتخطيط للدروس وتتفيذها، وتتويعها، وعلاقات اجتماعية، وتقاعلات صفية، ونقد، وتقويم، وقيادة تريوية، ومواجهة مشكلات، والتزام بقواعد إدارية، وخلقية، واتجاهات، وقيم متعلقة بههنة التدريس.وتسعاعد الممارسـات المتتوعة من ورش تدريبية ، ودروس نموذجية وتدريس مصغر، وتبادل الزيارات بين المتدربين، وتوظيف وسـائل التواصل الاجتماعي ٌِّ خلق تلك البيئة الفاعلة بين المشاركين ِّ برنامج التربية الميدانية، ودعم الطلاب المعلمـين بأسلوب التدريس التفاعلي الحديث، مها يساعد ِِّ بناء اتجاهات إيجابية نحو برامج التربية الميدانية حيث أكدت دراسـة الزيود (2001) ودراسة ساند هولتز وشانون (Sandholtz S Shannon, 2000) ودراسة هوكلي (Hockly, 2000) على أهمية التدريب والتدريس المصغر يخ هذا المجال، وتشير دراسة مونوز وتوينر (Munoz \& Towner, 2009) أن شبكة الفيسبوك بإمكانها تحقيق فوائد للمعلم، والطالب على السواء من خلال تقديم طرائق، وأساليب حديثة للتدريس بدلا من الطرائق التقليدية ، وإنشاء مجتمعات التعلم الإلكتروني.كها تم التأكيد ِِّ العديد من الدراسـات على أنَّ شبكات التواصل الاجتهاعي انعكست على التعليم كأدوات تعليمية إثرائية ِِّ سياق التعلم غير الرسهي، ولها تأثير على الجوانب الوجدانية مها يؤدي لزيادة الرضا، والانخراط ِوْ التعله، والاحتفاظ به، والدافعية لدى الطلاب،وتتمية اتجاهاتهم الإيجابية، وتتيح مشاركة الخبرات، أو المواقف فو الحياة الجامعية، وتبادل المعارف العملية، والأكاديمية، وتتفيذ المهام، ومشاركة مصادر التعلم، وتتمية التقكير الناقد ، وإعادة التفكير لدى الطلاب.(عمر، 2013) ويظهر ما تقدم من نشاطات، ومهارسات أن المجال متاح للتوع الكبير، والتفاعل المهم مِ التربية الميدانية خلافاً لما هو سـائد من اقتصارها على نمط محدد لا يتطور، كها يظهر ذلك أن فعالية تلك النشاطات، والممارسات ِِّ التربية الميدانية، وتحقيق الأهداف المرجوة منها يستدعي كما يشير العيوني والفالح (2002) تعاون المعنيين بها ٍِّ القيام بأدوارهم على الوجه الأكمل من المشرف، وقائد المدرسة، والمعله المتعاون، والكلية، والمدرسة، والطالب المعلم نقسهـونظراً لأهمية التربية الميدانية، ودورها المحوري پِ إعداد المعلم فقد تتوعت الدراسـات التي تتاولتها من كافة جوانبها ، حيث كثفت دراسة كاريكو وستيفن (Kyriacou \& Stephens, 1999) 
عن وجود العديد من الاهتمامات الأساسية للمتدربين أثناء التربية الميدانية تركزت ِوْ عدم تشكيل، ومشـاركة وجهات نظرهم مثل المعلمـين الأساسيين، ومعاملتهم بطريقة متباينة، كها له يلمسوا احتراماً مناسباً لهم، وأن بعض التوجيهات من مشرفيهم كانت قاسية ، وصارمة ، وغير مبررة. كما توصلت دراسة بيك (Beck, 2002) إلى أنَّ نوع الدعم، والتغذية الراجعة المطلوبة التي يحتاج إليها الطالب المعلم، وآليات تزويده بها تتمثل ِّ توفير الدعم المعنوي من قبل المعلمـين المشاركين يخٌ التدريب، وعلاقة الأقران، أو الزمالة بالمعلمين المتعاونين، ودرجة التعاون معهم، كذلك مرونة المحتوى التعليهي، وطرق التدريس، وأثر التغذية الراجعة التي يتلقونها على إنجازهم، وكيفية تقديهها بطرق إنسانية ، وأخلاقية ، وعملية ، إضافة إلى مساعدة الطالب المعلم ليفهم كل ما يقال حول التعليم، والتعلم يِّ الغرفة الصفية الحقيقية، وحجهم العبء الملقى على عاتقه، وجميع ذلك يساعد ِِّ تقرير مستوى نجاح التربية الميدانية.وخلصت الخطيب (2004) يخ دراستها عن واقع التربية الميدانية إلى أن أهدافها كانت واضحة لدى غالبية عظهى من المشرفين عليها ، وأن برنامجها حقق أهدافه بدرجة متوسطة ، وكشفت الدراسة عن مشكلة فرض المعلم

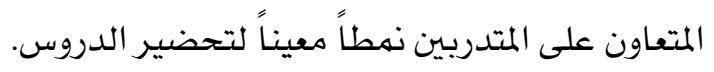
كما خلصت دراسة الأسطل (2004) إلى أنَّ أهم المشكلات التي تواجه الطلاب المعلمـين أثناء فترة التربية الميدانية كانت تتعلق بطبيعة برنامجها ، وكانت المشكاتلات التي تتعلق بطبيعة المشرف الأكاديهي أقل من ذلك، وِِّ الإطار ذاته توصلت دراسة العبادي (2004) إلى أن المشككلات الخمس الرئيسية التي تواجه الطلاب المعلمين تمثلت فِ قلة الوسائل التعليمية، وصعوبة توفيرها ِِّ المدارس المتعاونة، ومشكلة عدم التقرغ كلياً للتدريب العملي، وإشغال الطلاب المعلمـين بواجبات غير التدريس، كإشغال بعض الحصص، واعتماد بعض المعلمين المتعاونين على الطلاب المعلمين يخ تتفيذ حصصهم، ومشكلة كثرة عدد الطلاب يخ الصف الواحد.وتوصلت دراسة واليلين وفانتون (Walelign \& Fantahun, 2006) إلى وجود الكثير من القصور وِ التسهيلات الضرورية، والخدمات للمتدربين أثناء فترة التطبيق العملي، وأن نظام الإدارة للبرنامج التدريبي لا يعطي اهتماماً كافياً لتحقيق الاحتياجات للمتدربين، ولا يراعي اهتماماتهم، كما أشارت رغم ذلك إلى أن معظم المتدربين راضون عن سياسة التدريب العملي، وأن اتجاهاتهم نحو ههنة التعليم تتأثر بدرجة عالية بالنظرة المجتمعية العامة تجاه هذه المهنة.كها توصلت دراسـة شـاهين (2007) إلى أنَّ وجهات نظر الطلاب المعلميـين عن التربية الميدانية كانت 
إيجابية ِِّ معظم الممارسات وفقاً لمحاور البرنامج المحددة، والتي شملت: أهداف البرناهج،

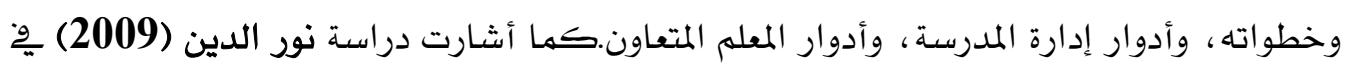

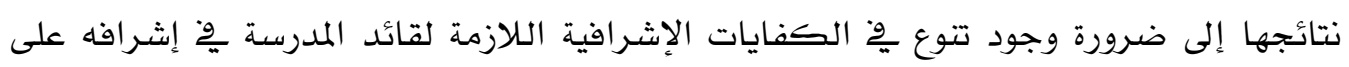
الطالب المعلم من كفايات إنسانية، وشخصية، وعامة، وعملية، و إدارية، وأدائية، ومهنية،

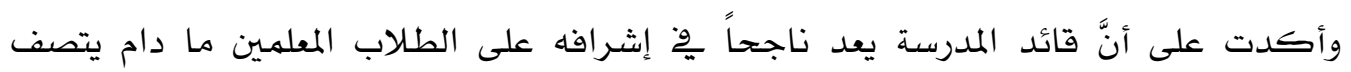

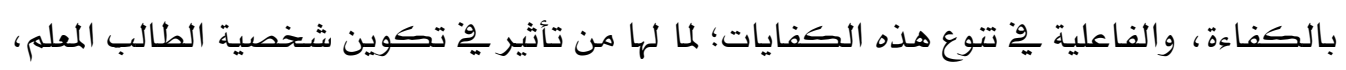
وتحقيق الدافعية له تجاه مهنة التعليم، وتشجيعه على الإبداع، والتجريب، والابتكار وِّ الميدان التعليهي المدرسي.وهدفت دراسة الزهراني (2013) إلى التعرف على دور مواقع التواصل

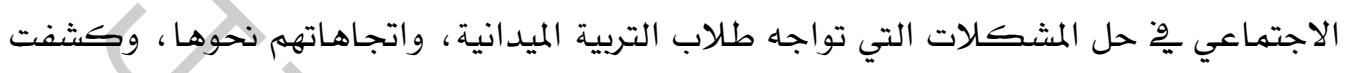

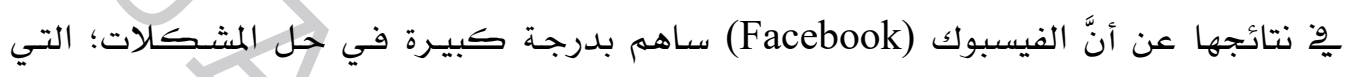
واجهتهم أثناء فتـرة التدريب، إضـافة إلى وجود اتجاهـات ايجابيـة لديهم نحو استخدام الفيسبوك في حل تلك المشـككلات، ووجـود معوقات تحـد مـن استخدامده وِ التدريب.واجرى شاهين (2015) دراسة هدفت الى التعرف على اتجاهات طلاب الجامعة الاسـلامية بالمدينة المنورة نحو مقرر طرق التدريس و التربية العملية ومهنة التعليم پِ ضوء بعض المتفيرات، واظهرت النتائج وجود اتجاهـات إيجابية بدرجة عالية نحو مقرر طرق التدريس، والتربية العملية ، إضافة إلى وجود علاقة ارتباطية بين اتجاهاتهم نحو المقررين، ووجود/فروق داله احصائياً فِ اتجاهاتهم تعزى لمتغير المستوى الدراسي، والكلية، وعدم وجود فروق داله احصائياً ِِّ اتجاهاتهم تعزى لمتغير المعدل

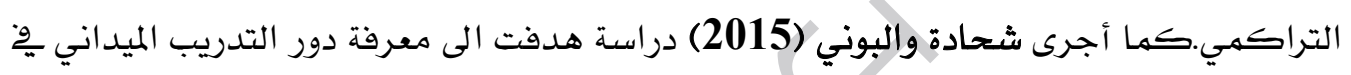
تغيير اتجاهـات طلاب كلية التربية بوادي الدواسر نحو مهنة التدريس، وأظهرت النتائج وجود دور إيجابي يخ تغيير اتجاهات الطلاب نحو مهنة التدريس، ووجود فروق نحو مهنة التدريس تعزى لمتغير الجنس لصالح الإناث، وكذلك توجد فروق بينهم تعزى لمتغير المعدل التراكهي لصالح المعدل

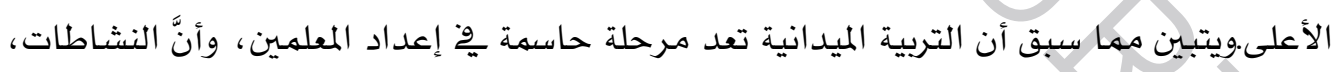

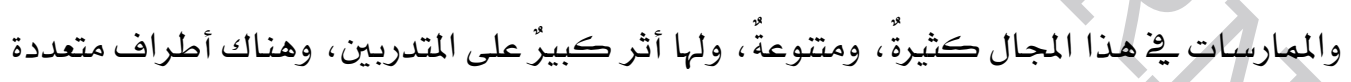

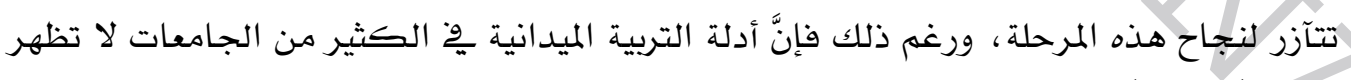

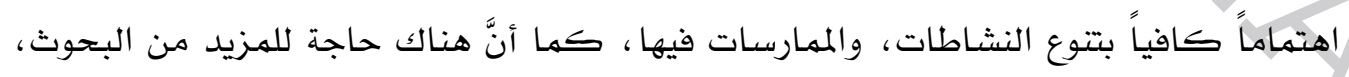
والدراسات العربية التي تركز على الاتجاهات يٌْ التربية الميدانية ودور الممارسـات، والنشاطات

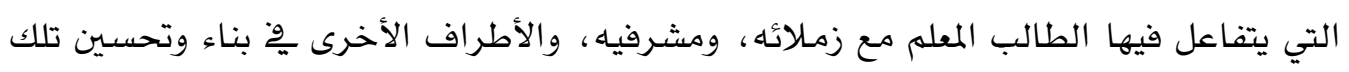


مشكلة الدراسة

تعد التربية الميدانية بهثابة الجسر الذي يربط بين ما تعلمه الطالب المعلم من معلومات، ومعارف نظرية خلال المستويات الدراسية السـابقة؛ ليمارسها على أرض الواقع أثناء التربية الميدانية

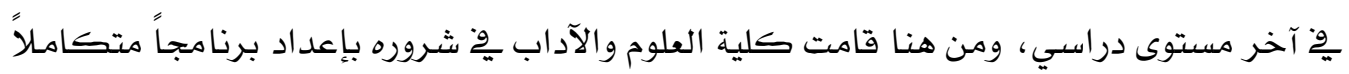
ِّخ التربية الميدانية أخذت فيه بها تشير إليه توصيات الدراسات، وخلاصات التجارب لإنجاح هذه

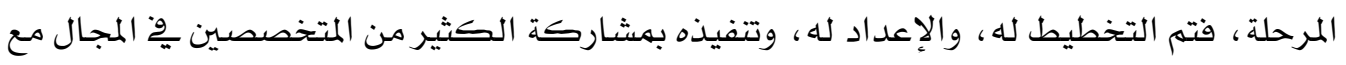

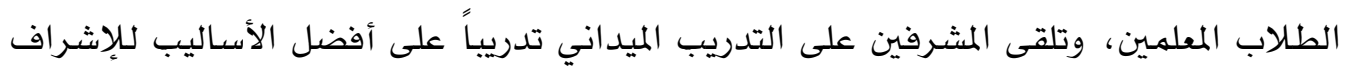

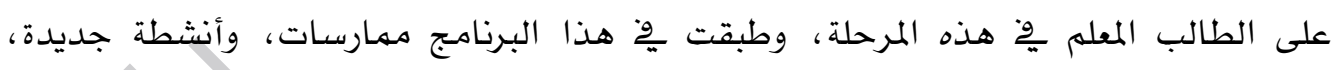
ومتتوعة، حيث يبدأ بتشخيص للطلاب المعلمين قِّ بداية الفصل الدراسي لمعرفة احتياجاتهم بِ التطوير، والتدريب، والدعم، ثم يكون هناك اللقاء التعريفي، والتحفيزي، والذي يركز على أهمية التدريب الميداني، وانعكاساته على مستوى المعلم لاحقاً ، كما يشتمل هذا البرناهج على ولى ولى

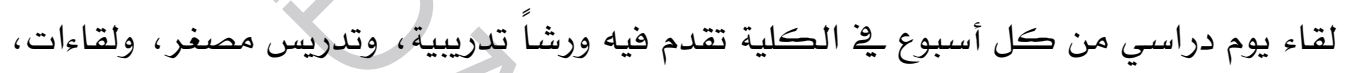
إضافة إلى التسسيق مع مكتب التعليم لإتاحة الفرصة لهم للمشاركة يّْ دورات أخرى -حسب

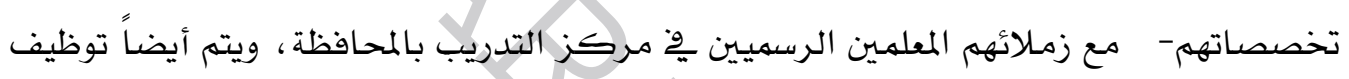
وسائل التواصل الاجتماعي المختلفة ِِّ تبادل الخبرات، والأفكار، والنشاطات، والتفاعل بين المدربين أنقسهم، ومع مشرفيهم، وحضور حصص تدريسية لمعلمـين متميزين يخ تخصصهم على مستوى المحافظة، واستضافة معلمين خبراء، ومشرفين ِخ الميدان؛ للحديث عن واقع التعليم، وتحدياته، وأساليب التعامل معها.

كما أن هناك تصورات، واتجاهـات مسبقة لدى الطلاب المعلمـين عن برنامج التربية الميدانية، وعن الممارسـات المطلوبة منهم خلال فتره التدريب العملي، و بالتالي يتوقع أن تحدث

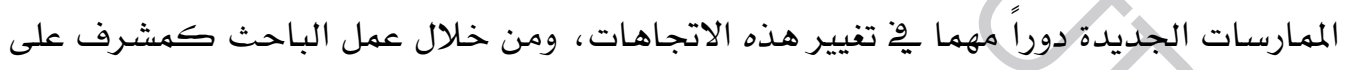
برناهج التربية الميدانية بالكلية فقد شعر بأهمية استقصاء تلك الاتجاهات وتطورها ِخْ ضوء ما تم من مهمارسات، ونشاطات أثناء تتفيذ البرنامج، وعلاقة هذا التغيير ببعض من المتغيرات

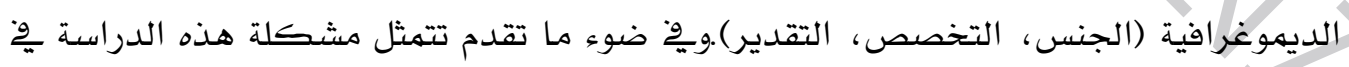
هحاولة تعرف اتجاهات الطلاب المعلمين بكلية العلوم والآداب بشرورة نحو برنامج التربية الميدانية ، وما تضهنه من مهارسـات، ونشاطات متتوعة تقدم داخل المدرسة، و وِّ الكلية.وعليه يمكن أن تتلخص مشكلة الدراسة يخٌ الأسئلة الآتي: 
السؤال الأول والرئيس: ما نوع وشدة اتجاهـات الطلاب المعلمين نحو برناهج التربية الميدانية بكلية

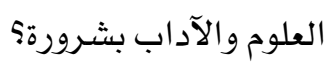

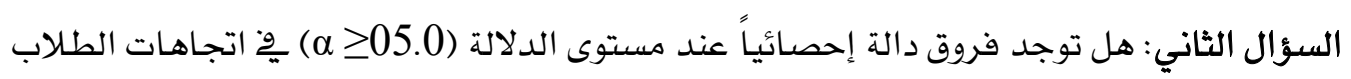
المعلمـين نحو برنامج التربية الميدانية بكلية العلوم والآداب بشرورة تعزى لمتغير الجنس؟

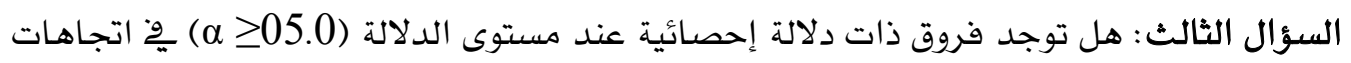
الطلاب المعلمـين نحو برنامج التربية الميدانية بكلية العلوم والآداب بشرورة تعزى لمتغير التخصص؟

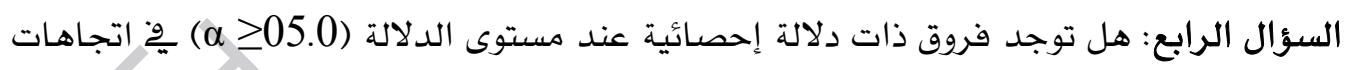
الطلاب المعلمـين نحو برنامج التربية الميدانية بكلية العلوم والآداب بشرورة لمتفير التقدير؟

$$
\text { أهداف الدراسة }
$$

اتجاهات الطلاب المعلمـين نحو برنامج التربية الميدانية بشكل عام. اتجاهـات الطلاب المعلمـين نحو الممارسـات والنشاطات المختلفة التي يتم تتفيذها من خلال برنامج التربية الميدانية.علاقة بعض

$$
\begin{aligned}
& \text { المتغيرات باتجاهـات الطلاب المعلميـن نحن التربية الميدانية. } \\
& \text { أهمية الدراسة } \\
& \text { يهكن للدراسة الحالية أن تقيد يوخ المجالات التالية : }
\end{aligned}
$$

1. تكشف الدراسة يخ إطارها النظري عن أهمية تطوير برامج التربية الميدانية كهرحلة أسـاسية ِِخ إعداد المعلمين، وأهمية اشتمالها على نشاطات، وممارسات تتاسب الواقع المعاصر، مع مساهمة، وتقاعل كل الأطراف المعنية يخ تلك النشاطات، والممارسـات تقيد

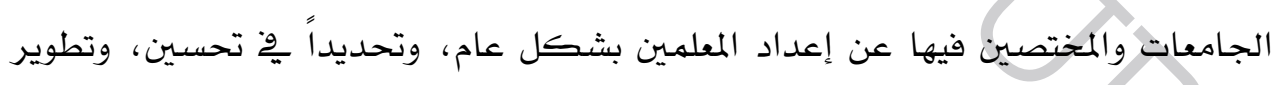
برامج التربية الميدانية من كافة جوانبها المساهمة يخٌ إثراء الدراسات والأبحاث التي تتاولت الاتجاهات نحو برامج التربية الميدانية ِوْ الجامعات، والكليات.

\section{مصطلحات الدراسة الإجرائية}

برنامج التربية الميدانية: هو الجانب التطبيقي المكمل لبرنامج إعداد المعله؛ الذي يعطى ِّ2 كلية العلوم والآداب بشرورة لمدة فصل دراسي واحد بواقع ثمان ساعات معتمدة ، ويتم فيه التدرب على مهارسة الأسس والخبرات اللازمة للبدء بعملية التدريس، حيث يقضي الطالب المعلم فصلاً 
كاملاً يمارس فيه التدريس فِ إحدى مدارس التعليم العام، تحت إشراف مشرفين متخصصين، ويتخلل ذلك مهمارسته لمجموعة من النشاطات، والممارسات التدريبية المتتوعة، والمخطط لها،

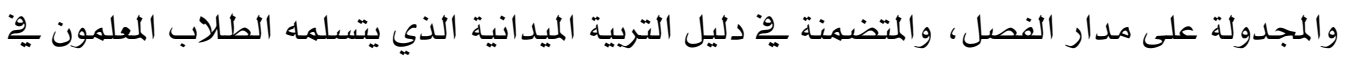

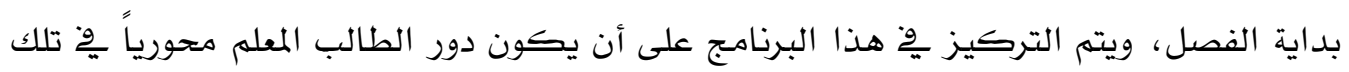
النشاطات من خلال مشاركته الفاعلة، پِّ تبادل الخبرات، وتقديم أفكاره، ومقترحاته، وإنجازاته، والمشاركة ِّْ حوارات، ونقاشات حولها، وحول ما يواجهه من صعوبات، أو مشككلات، مع زمهلائه المتدربين، وبهشاركة وإشراف المشرفين المختصسين، والأطراف الأخرى قوِ التربية الميدانية من المعلمين المتعاونين، وقادة المدارس، وغيرهم، ويشرع الطلاب المعلمون ِّ البرنامج بعد اختبار تشخيصي پِّ بداية الفصل الدراسي للتعرف على الاهتمامات، والاتجاهـات، والحاجات، وجوانب القوة والضعف، وتحديد أولويات نشاطات، ومهارسيات البرناهج ِخ ضوء ذلك، ومن تلك النشاطات، والمهارسـات التي يتضمنها البرنامج: المثناركة وِ الورش التدريبية، والتعليم المصفر، والدروس النموذجية، ومجموعات منظمة ومتخصصة بالمجال وِ شبكات التواصل الاجتهاعي، والتعلم الإلكتروني، إضافة إلى حضور اللقاءات، والورش، والدروس النمـوذجية مع المدرسـين السـابقين أصحاب الخبرة، والأداء المتميز. الطالب المعلم: يقصد به يخ هذه الدراسة الطالبة، أو الطالب المنتظم، أو المنتسب بِّ أقسام كلية العلوم والآداب بشرورة (الدراسات الإسلامية، واللفة العربية، وعلوم الحاسب، واللغة الإنجليزية، والرياضيات، والكيهياء) ِِح المستوى الثامن، والذي يُنفذ مراحل برناهج التربية

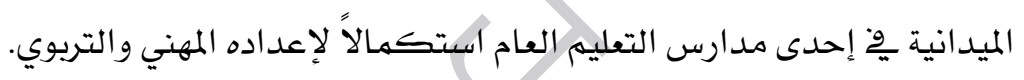
الاتجاه نحو التربية الميدانية: استجابات الطالبات، والطلاب المعلمين يخ كلية العلوم والآداب بهحافظة شرورة بالقبول، أو الرفض تجاه مناشط التربية الميدانية. ويقاس بالدرجة التي يحصل عليها الطلاب المعلمون (عينة الدراسة) ِِّ مقياس الاتجاه.

حدود الدراسة الحدود الموضوعية: اقتصرت الدراسـة على دراسـة اتجاهات الطالبات، والطلاب المعلمـين نحو برنامج التربية الميدانية ِخ ضوء ما اشتمل عليه من نشاطات ومهارسات متتوعة الحدود المكانية : أجريت الدراسة يخٌ كلية العلوم والآداب بشرورة إحدى كليات جامعة نجران. الحدود البشرية: تم استطلاع آراء الطالبات، والطلاب بالكلية. 
الحدود الزمنية: تم تطبيق هذه الدراسة خلال الفصل الدراسي الثاني من العام الدراسي

$$
\text { 1437-1436) }
$$

منهج الدراسة

استخدمت الدراسـة المنهج الوصفي التحليلي، وذلك عن طريق تطبيق مقياس الاتجاه الذي تم

$$
\text { تطويره من الباحث لهذا الغرض. }
$$

مجتمع الدراسة وعينته

تكوّن مجتمع الدراسة من جميع طلاب، وطالبات التدريب الميداني الذين يدرسون مقرر التربية الميدانية يخ كلية العلوم والآداب بشرورة للعام الدراسي (1437/1436هـ). وتمثلت عينة الدراسة ِحْ المجتمع كامـلاً لمحدوديته حيث بلغت العينة (65) طالباً، وطالبة، منهم (31) طالباً، و (34) طالبة. والجدول رقم (1) يوضتح توزيع مجتهع، وعينة الدراسة حسب متغيراتها.

\begin{tabular}{|c|c|c|c|}
\hline النسبة & التكرار & الفئات & المتغير \\
\hline 7.47 & 31 & متدرب / طالب & \multirow{2}{*}{ الجنس } \\
\hline 3.52 & 34 & متدربة / طالبة & \\
\hline 2.29 & 19 & دراسـات إسـلامية & \multirow[t]{5}{*}{ القسم } \\
\hline 3.12 & 8 & لغة عربية & \\
\hline 1.23 & 15 & لغة إنجليزية & \\
\hline 8.10 & 7 & رياضيات & \\
\hline 6.24 & 16 & حاسب آلي & \\
\hline 1.3 & 2 & مقبول & \multirow{4}{*}{ التقدير } \\
\hline 0.40 & 26 & جيد & \\
\hline 7.47 & 31 & جيد جداً & \\
\hline 2.9 & 6 & مهتاز & \\
\hline$\% 100$ & 65 & & \\
\hline
\end{tabular}
جدول رقم (1) توزيع أفراد عينة الدراسة بحسب المتفيرات: الجنس، والقسم، التقدير

أداة الدراسة

قام الباحث بتطوير أداة الدراسـة (مقياس الاتجاهـات) بعد الاطلاع على الأدب التربوي المتصل بها ، وقد بلغ عدد فقرات المقياس (20) فقرة منها (13) فقرة إيجابية ، و (7) فقرات سلبية. وتم التمات 
تدريج فقرات المقياس بطريقة ليكرت، حيث تقع الإجابة على كل فقرة ِِّ الأداة، ضمن سلم

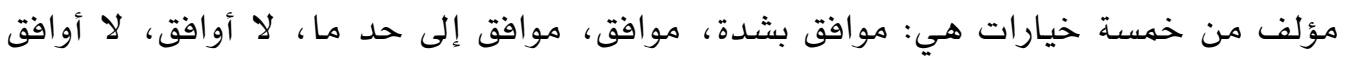

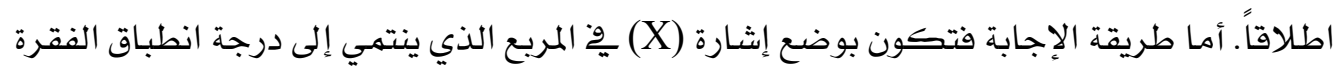

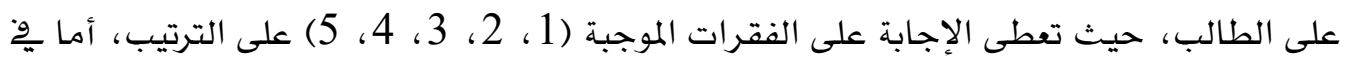
حالة العبارات السالبة فيتم عكس الاستجابات لتصبح (5، 4، 3، 2، 2، 1) لنفس الإبه الاستجابات السابقة على الترتيب. صدق أداة الدراسة

للتحقق من صدق المقياس تم عرضـه بصـورته الأوليـة على مجموعة مـن المحكمـين بِّ مجـال

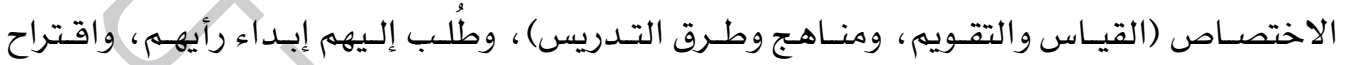

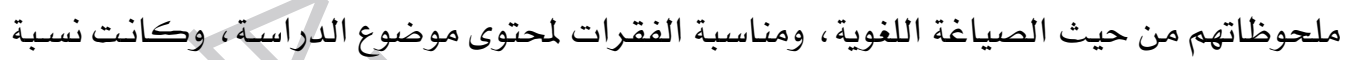

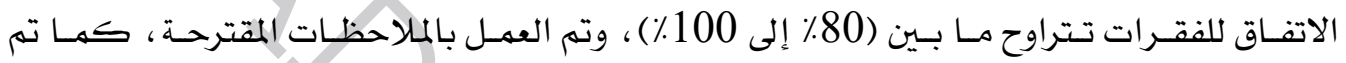

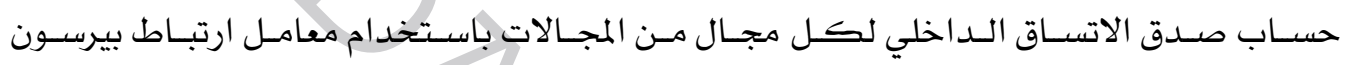

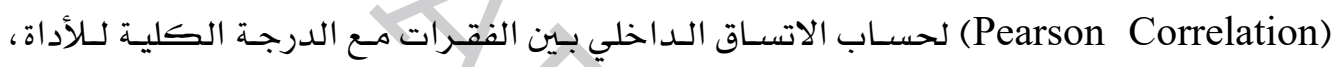

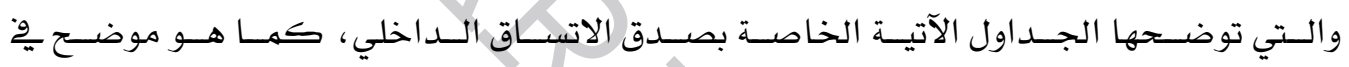
جدول رقم (2).

جدول (2) معامل الارتباط بين كل فقرة من الفقرات مع الدرجة الكلية للمقياس

\begin{tabular}{|c|c|c|c|c|c|}
\hline مستوى الدلالة & معامل الارتباط & الرقم & مستوى الدلالة & معامل الارتباط & الرقم \\
\hline دال عند 0.01 & $* * 0.441$ & 11 & دال عند 0.01 & $* * 0.471$ & 1 \\
\hline دال عند 0.01 & $\$ * 0.458$ & 12 & دال عند 0.01 & $\$ * 0.497$ & 2 \\
\hline دال عند 0.01 & $\$ 40.486$ & 13 & عند 0.01 & $\$ .0 .493$ & 3 \\
\hline دال عند 0.01 & $\star * 0.768$ & 14 & دال عند 0.01 & $\star 40.675$ & 4 \\
\hline دال عند 0.01 & $\$ 0.690$ & 15 & دال عند 0.01 & $\$ 0.559$ & 5 \\
\hline دال عند 0.01 & $* 0.674$ & 16 & دال عند 0.01 & $\$ 0.400$ & 6 \\
\hline دال عند 0.01 & $* 0.663$ & 17 & دال عند 0.01 & $* 0.587$ & 7 \\
\hline دال عند 0.01 & $\$ 0.666$ & 18 & دال عند 0.01 & $\$ * 0.574$ & 8 \\
\hline دال عند 0.01 & $* * 0.479$ & 19 & دال عند 0.01 & $* 0.449$ & 9 \\
\hline دال عند 0.01 & $* * 0.503$ & 20 & دال عند 0.01 & $\$ * 0.567$ & 10 \\
\hline
\end{tabular}


ويتضح من الجدول رقم (2) أن جميع الفقرات مرتبطة ارتباطاً موجباً وذو دلالة إحصائية بين الفقرات والدرجة الكلية عند مستوى (0.01) وهي مقبولة ، ولم يتم حذف أي من الفقرات ثبات

بعد تطبيق أداة الدراسة على العينة، تم حساب معامل الثبات للأداة عن طريق استخدام معادلة (ألفا كرونباخ) للاتساق الداخلي، حيث بلفت قيمة معامل الثبات للأداة (814.0) وهذه القيهة مقبولة تريويًا لمعامل الاتساق الداخلي يِّ حدود أغراض هذه الدراسة، وطبيعتها. المعالجة الإحصائية

بعد الانتهاء من عملية جمع البيانات فرغت وأدخلت الحاسب الآلي، وعولجت باستخدام

برنامج الرزم الإحصائية للعلوم الاجتماعية (SPSS)، وباستخدام المعالجات الإحصائية التالية: - المتوسطات الحسابية، والانحرافات المعيارية؛ للإجابة عن سؤال الدراسة الأول المتعلق باتجاهات الطالبات والطلاب المعلمـين نحو التربية الميدانية.- اختبار (ت) لمجموعتين مستقلتين (Independent T.test) للإجابة عن سؤال الدراسة الثاني فيما يتعلق بهتغير

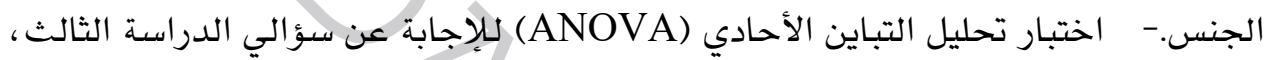
والرابع فيما يتعلق بهتغيري القسه، والتقدير.- - معامل الارتباط بيرسون لحساب صدق الاتساق الداخلي بين فقرات الأداة، والدرجة الكلية نلأداة.- معادلة ألفا كرونباخ لحساب معامل ثبات الأداة. (Alpha Chronbach)

نتائج الدراسة

النتائج المتعلقة بالسؤال الأول والرئيس للدراسة والذي ينص على التالي: ما نوع وشدة اتجاهات الطلاب المعلمين نحو برنامج التربية الميدانية بكلية العلوم والآداب بشرورة؟ للإجابة عن هذا السؤال تم حساب المتوسطات الحسابية، والانحرافات المعيارية، والرتب لكل فقرة من فقرات الأداة، وللحكم على شدة الاتجاه تم تصنيف المتوسطات إلى ثلاثة مستويات (مرتفع، متوسط، متدني). ويتبين ذلك من خلال الجدول رقم (3). الجدول رقم (3) تقديرات المتوسطات الحسابية

\begin{tabular}{|c|c|}
\hline شدة الاتجاه & القيمة \\
\hline ضعيف & $33 ، 2-1$ \\
\hline متوسط & $3,66-2,34$ \\
\hline مرتقع & $5-3,67$ \\
\hline
\end{tabular}

وللحكم على نوع الاتجاه تم اعتماد الدرجة (من 1- أقل من 2.5) للاتجاه السلبي، و (من 2.5 
جدول رقم (4) المتوسطات الحسابية، والانحرافات المعيارية، والرتبة لاتجاهات الطالبات، والطلاب المعلمين نحو برنامج التربية الميدانية على جميع فقرات المجال

\begin{tabular}{|c|c|c|c|c|c|c|}
\hline تيب & نو الاتجاه & شدة اتجاه & 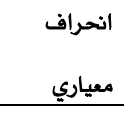 & متوسط & 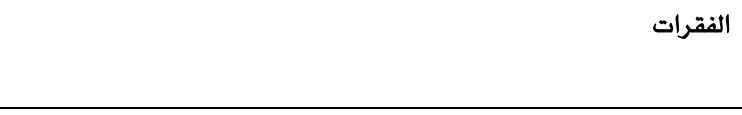 & رقم \\
\hline 1 & ايجابي & 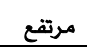 & 0.82334 & 4.6154 & شعرت بالفائدة بشكل عام من برنامج التربية الميدانية. & 6 \\
\hline 2 & ايجابي & 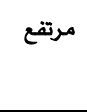 & 0.70472 & 4.5846 & أو الكلفت من توجيهات المشرف الأكاديمي يِّ الزيارات واللقاءات بِّ المدرسة & 3 \\
\hline 3 & ايجابي & مرتفع & 0.77304 & 4.4923 & استفدت من الممارسة الفعلية، والبيئة المدرسية، والزملاء بِّ المدرسة بشكل & 15 \\
\hline 4 & ايجابي & مرتفع & 0.86241 & 4.4000 & تعلمت من الدورات، والورش التدريبة، واللقاءات التي قدمها القسم. & 7 \\
\hline 5 & ايجابي & & 118 & 4.3231 & مهارات التدريس لدي. أمشاركات والحوارات والنقاشات يُّ تطبيق الواتس آب يُّ تتمية & 10 \\
\hline 6 & ايجابي & 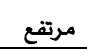 & 0.92715 & 4.2769 & شعرت باحترام شخصيتي أثناء التربية الميدانية. & 2 \\
\hline 7 & ايجابي & مرتفع & 0.92690 & 4.2154 & أحب المشاركات والحوارات والنقاشات يُّوسائل التواصل بشكل عام & 1 \\
\hline 8 & ايجابي & 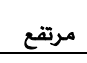 & 1.00312 & 4.2000 & أتمنى زيادة اللقاءات، والتوجيهات، والزيا & 18 \\
\hline 9 & ايجابي & 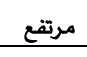 & 0.99808 & 4.1385 & أرغب يُّ المزيد من التفاعل والمشاركة يِّكل فعاليات التربية | & 19 \\
\hline 10 & ايجابي & 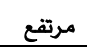 & 1.17935 & 3.8769 & استمتعت بحضور دروس لمعلمين قدامى متميزين جِّ ا| & 9 \\
\hline 11 & ايجابي & 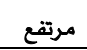 & 1.34486 & 3.8615 & وقت توجيهي للمدرسة كان مناسباً. & 11 \\
\hline 12 & ايجابي & متوسط & 1.50080 & 3.5385 & 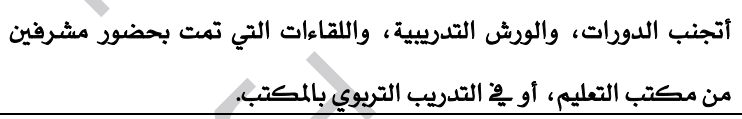 & 16 \\
\hline 13 & ايجابي & 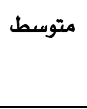 & 1.51006 & 3.3408 & شعرت بالضيق من توجيهات المشرف التريوي يخ الزيارات، واللقاءات معه بِّ & 20 \\
\hline 14 & ايجابي & متوسط & 1.45245 & 3.2769 & توجيهات قائد المدرسة أثناء الزيارات واللقاءات معه مملة. & 12 \\
\hline 15 & ايجابي & 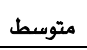 & 1.43363 & 3.2308 & طريقة توجيهي للمدرسة كانت غير مناسبة. & 14 \\
\hline 16 & ايجابي & 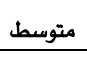 & 1.34772 & 3.1077 & مجالات تقويم أدائي يخ التربية الميدانية تتسم بالغموض. & 17 \\
\hline 17 & ايجابي & 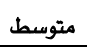 & 1.37753 & 3.0923 & فائدتي ضعيفة هِّ مرحلة المشاهدة يوٌ التدريب الميداني. & 4 \\
\hline 18 & ايجابي & متوسط & 1.38883 & 3.0923 & أحب المشاركات والحوارات والنقاشات ِِّ برنامج فيس بوك. & 5 \\
\hline 19 & ايجابي & 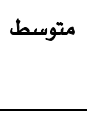 & 1.37945 & 2.8154 & (بلاكره المشاركات، والحوارات، والنقاشات من خلال التعليم الإلكتروني & 13 \\
\hline 20 & سلبي & 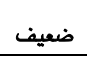 & 1.27325 & 2.1385 & أثر المشاركات، والحوارات، والنقاشات فِّرنامج تويتر كان ضعيفاً. & 8 \\
\hline & ايجابي & مرتفع & 0.55503 & 3.7347 & 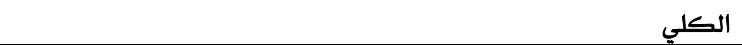 & \\
\hline
\end{tabular}


يتضح من نتائج الجدول رقم (4) أن الاتجاه العام للطالبات والطلاب المعلمـين نحو برنامج التربية الميدانية جاء إيجابياً، وبدرجة مرتقعة، حيث بلغ المتوسط الحسابي للمقياس كاملاً

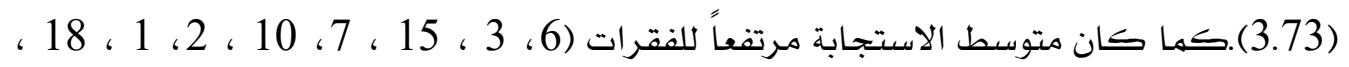
19 ، 9، 11)، وكان متوسطاً للفقرات (16، 20، 12، 14، 14، 14، 4، 5، 5، 13)، بينها نالت فقرة واحدة متوسط استجابة ضعيفاً، ورقهها (8) ونصت على "أثر المشاركات والحوارات

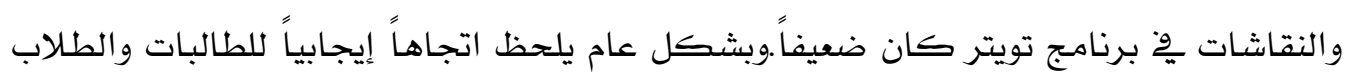
المعلمين نحو برنامج التربية الميدانية، ويعزو الباحث ذلك إلى ما لمسها الطلاب من فائدة لتلك الممارسات، ويعزو الباحث النتيجة الى النقاط التالية: 1 - توظيف خبرات أعضاء هيئة التدريس المتميزة ِ2 الكلية، وتقعيل دورهم مِ2 الإشراف على الطلاب المعلمـين، وإتاحة الكثير من الفرص لهم لتزويد الطلاب المعلمـين بجميع ما يتمتعون به من خبرات، ومعلومات، وتجارب، وأفكار يٌْ مجال التدريس، وههاراته.2 2- بناء علاقة متميزة مع مكتب التعليم مِّ شرورة أدى إلى الإفادة القصوى من المشرفين

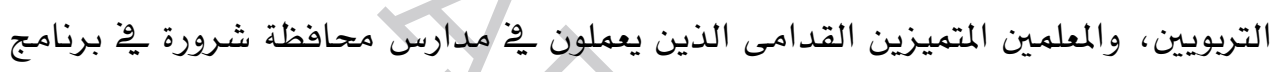
التربية الميدانية من خلال تقديم دروس أمام الطلاب المعلمين، مها كان لها دور ِِ إثراء

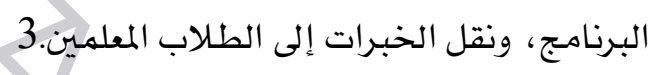
3- كان للورش التدريبية دور بخ استرجاع الطلاب للمعلومات، والمهارات السابقة التي تعلموها يخ مستويات سـابقة، وإضافة ممارسات جديدة، والتي شملت كافة مهارات التدريس بإشـراف مباشر من أعضاء هيئة التدريس. 4- استخدام وسـائل التواصل الاجتهاعي مثل الفيس بوك، و الواتس آب ِِخ البرنامج بفاعلية،

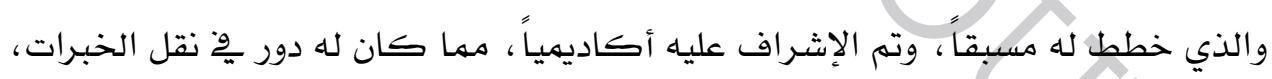
ومعالجة الصعوبات، وإثراء المناقشات، والحوارات بين الطلاب المعلمـين أنفسهم، ومع مشرفيهم، ويسرت التواصل مهما تباعدت المسافات، حيث تم إنشاء مجموعات مغلقة تستمر طيلة الفصل الدراسي تقتصر فقط على طلاب التدريب الميداني، ومشرفيهم، وينحصر

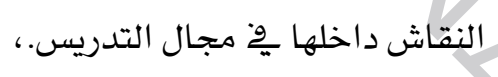

ويتقق ذلك ما تؤكده دراسـات هارتر (Harter,2011)، وعمر (2013)، وبيك (2002,

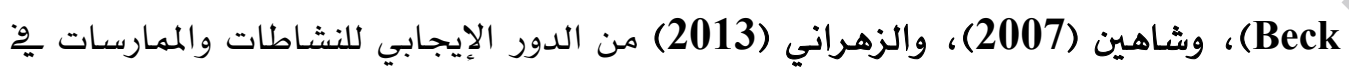
تحسين الاتجاهات وتطوير أداء المتدربين أما الفقرة رقم (8) والتي كان متوسط استجابتها 
ضعيفاً فقد يعود إلى أن إمكانية استخدام تويتر كانت محدودة، وفيها بعض الصعوبات پِ التفاعل مقارنة بها كان عليه الأمر ٍِِِ وسائل التواصل الأخرى، وخصوصا الواتس آب،

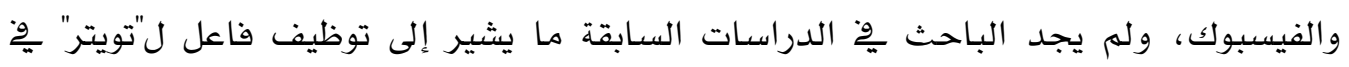
النشاطات، والممارسات التعليمية خلافاً لغيره من شبكات التواصل الأخرى. النتائج المتعلقة بالسؤال الثاني: والذي ينص على التالي: هل توجد فروق دالة إحصائياً عند

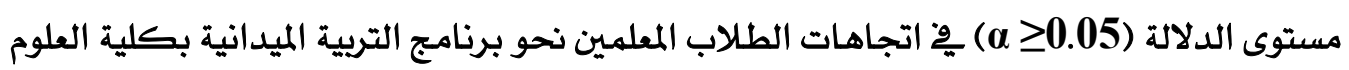
والآداب بشرورة تعزى لمتفير الجنس؟

وللإجابة عن هذا السؤال تم حسـاب المتوسطات الحسـابية ، والانحرافات المعيارية لاستجابات أفراد العينة على الأداة، كما تم استخدام اختبار (ت) للعينات المستقلة لدلالة الفروق بين المتوسطات، كما يوضحه الجدول رقم (5). الجدول رقم (5) المتوسطات الحسابية والانحرافات المعيارية لاتجاهات الطلاب المعلمين نحو برنامج التربية الميدانية بكلية العلوم والآداب بشرورة تبعا لمتغير الجنس، ونتائج اختبار (ت) للعينات المستقلة لدلالة الفروق بين المتوسطات

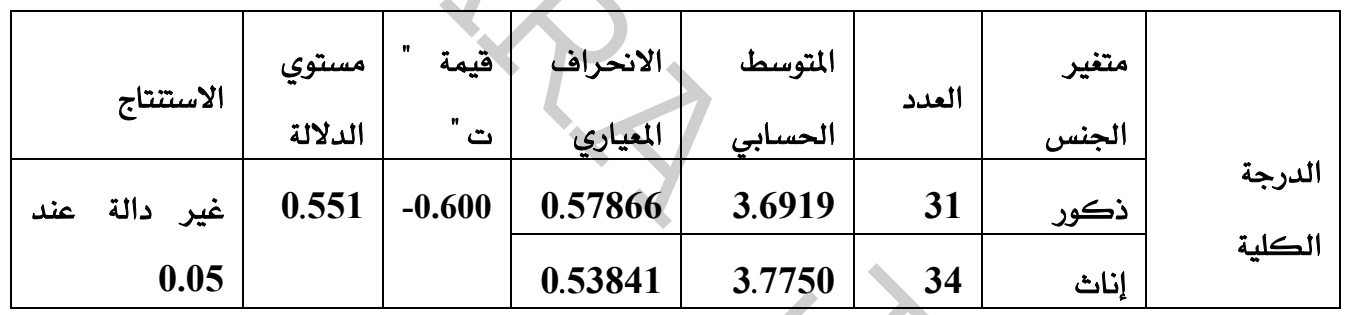
هال هال $\alpha \geq 0.05$ (إحصائيا عند مستوى الدلالة يتضح من الجدول رقم (5) السـابق عدم وجود فروق ذات دلالة إحصائية عند مستوى الدلالة

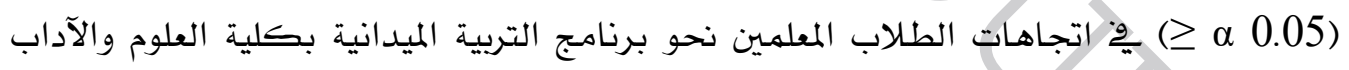
بشرورة تبعًا لمتغير الجنس، ويعزو الباحث هذه النتيجة إلى تشابه أنواع الممارسات، والنشاطات لدى الطالبات المعلمات، والطلاب المعلمين، والإشراف عليها من قبل لجنة مشتركة مشكلة من أعضاء، وعضوات هيئة التدريس، وتتفق هذه النتيجة مع ما توصلت له دراسة شـاهين (2007)، وعمر (2013)، وتختلف مع دراسة خوالدة (2010)، ويعود ذلك بِّ رأي الباحث لاختلاف بيئة الدراسة، وهجالها حيث ركزت على المشكلات التي تواجه الطالبات، والطلاب المعلمين خلافاً لهذه الدراسـة؛ التي ركزت على الاتجاهات. 
النتائج المتعلقة بالسؤال الثالث والذي ينص على التالي: هل توجد فروق ذات دلالة إحصائية

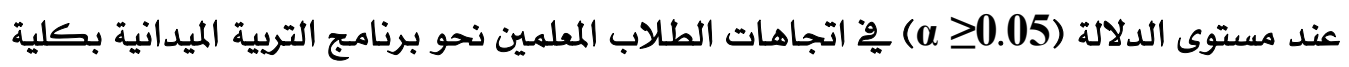
العلوم والآداب بشرورة تعزى لمتغير التخصصى للإجابة عن هذا السؤال تم استخراج المتوسطات الحسابية، والانحرافات المعيارية لاستجابات أفراد العينة على الاداة، كما تم استخدام تحليل التباين الاحادي لاستخراج دلالة الفروق على هلى الدرجة الكلية للأداة تبعًا لمتغير التخصص، كها يوضحه الجدول رقم (6) ورقم (7). الجدول رقم (6) المتوسطات الحسابية والانحرافات المعيارية لاستجابات العينة على مقياس اتجاهات الطلاب المعلمين نحو برنامج التربية الميدانية بكلية العلوم والآداب بشرورة تبعا

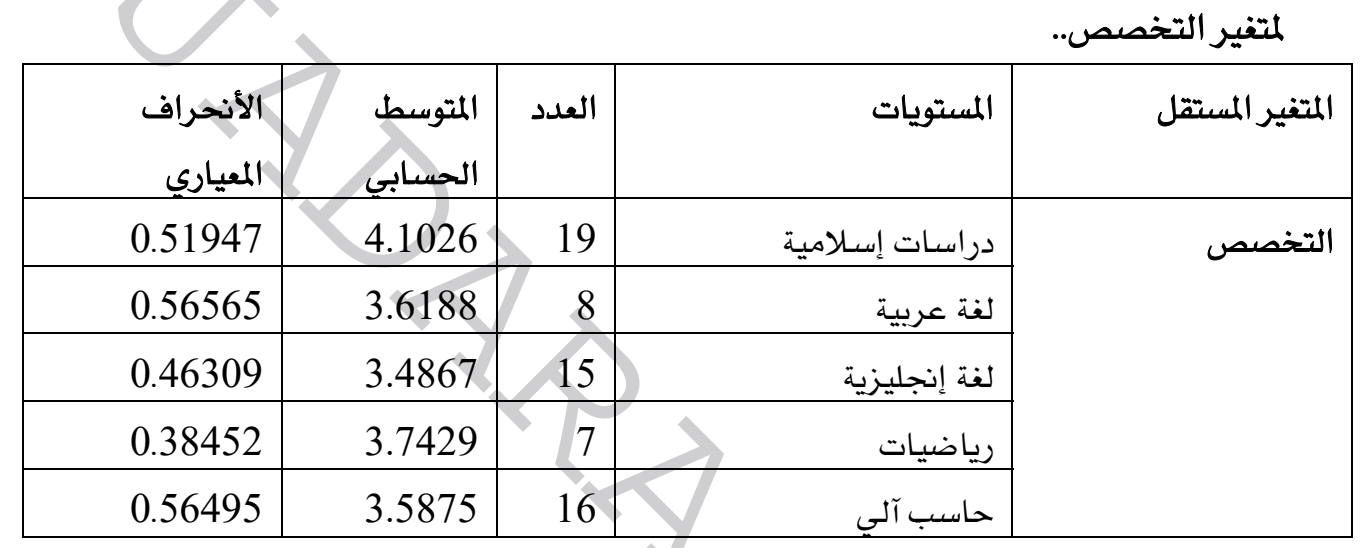

يلاحظ من الجدول (6) وجود فروق ظاهرية بين المتوسطات الحسابية وفقا لمتفير القسم، وللكشف عن دلالة الفروق بين المتوسطات استخدم تحليل التباين الأحادي (ANOVA)، ويبين الجدول رقم (7) هذه النتائج: الجدول رقم (7) نتائج تحليل التباين الأحادي للكشف عن دلالة الفروق يخ اتجاهات الطلاب المعلمين نحو برنامج التربية الميدانية بكلية العلوم والآداب بشرورة تبعا لمتغير التخصص.

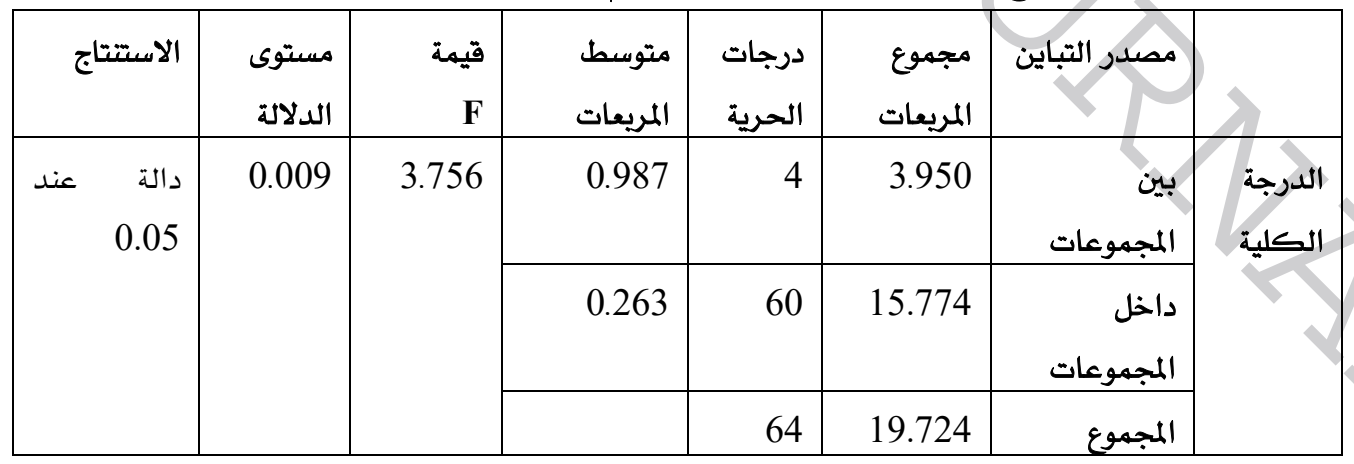

دال إحصائيا عند مستوى الدلالة ( $\alpha \geq 0.05)$ 


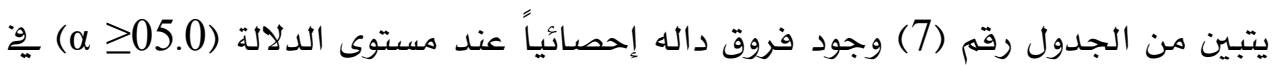
اتجاهـات الطلاب المعلمين نحو برنامج التربية الميدانية بكلية العلوم والآداب بشرورة تبعا لمتغير التخصص، فكانت قيمة ف (3.756)، ومستوى دلالتها (0.009). وللكشف عن الفروق فِ متغير التخصص استخدم الأسلوب الإحصائي (شيفيه) للمقارنات البعدية، كما هو مبين ِّ الجدول رقم (8).

جدول (8) اختبار شيفيه للمقارنات البعدية على مقياس اتجاهات الطلاب المعلمين نحو برنامج التربية الميدانية بكلية العلوم والآداب بشرورة تبعا لمتفير التخصص

\begin{tabular}{|c|c|c|c|c|c|c|}
\hline اتجاه الفرق & حاسب & رياضيات & لغة إنجليزية & لغة عريية & دراسـات & متغير القسم \\
\hline الدراسلح الدات الإسـلامية & 0.5151 & 0.3598 & 0.6160 & 0.4839 & - & دراسـات \\
\hline & -0.0312 & 0.1241 & 0.1312 & - & - & لغة عريية \\
\hline & 0.1008 & 0.2562 & - & - & - & لغة إنجليزية \\
\hline & 0.1554 & & - & - & - & رياضيات \\
\hline & & 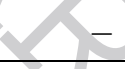 & - & - & - & حاسب آلي \\
\hline
\end{tabular}

هال هإل

يتبين من الجدول (8) أن متوسط الفرق بين استجابات قسهم الدراسـات الإسـلامية ، وقسمى اللفة الانجليزية (0.6160) جاء لصالح قسهم الدراسـات الإسـلامية، ويعزو الباحث هذه النتيجة يخ

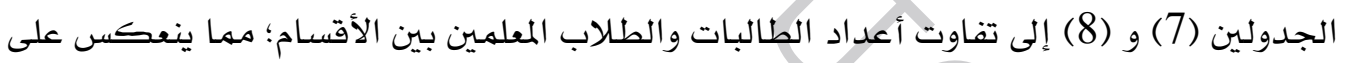
تبادل الخبرات، والتفاعل وِّ كل قسهم، وتتوعها بين أقسام أدبية، وأخرى علمية، فهثلاً هناك

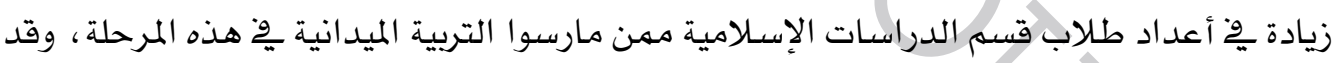
تعود هذه النتيجة أيضاً لاختلاف مادة طرق التدريس، واستراتيجياته، وأعضاء هيئة التدريس القائمـين بها هِ كل تخصص، والتي يدرسها الطالب قبل دخوله يخ مرحلة التدريب الميداني،

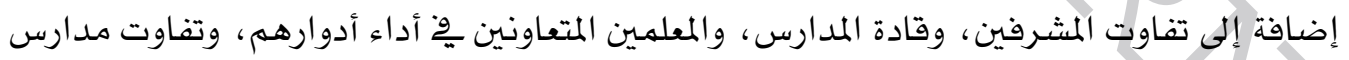

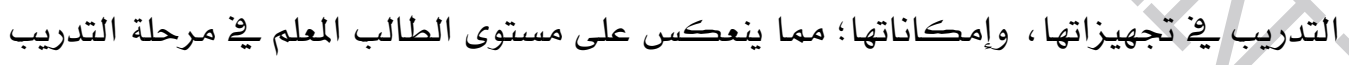
الميداني، ولعل هذا الاستتاج يتوافق مع دراسات عديدة من أبرزها دراسة كاريكو وستيفن

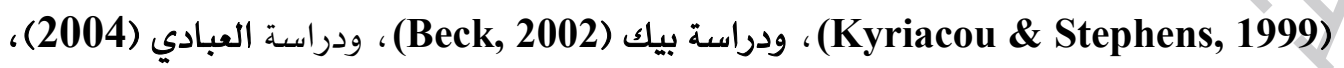

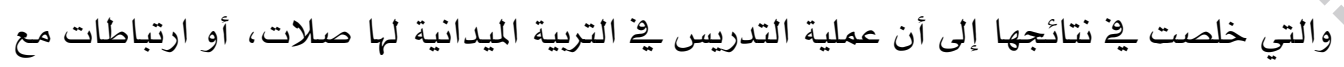
مسائل أخرى كالسلوك الإداري، والعلاقات بين المعلمـين، ومدى تفرغ الطالب المعلم، ودور المعلم 
المتعاون، ودور المشـرف، والإدارة الفاعلة، وما يلمسه الطالب المعلهم من كل أولئك من احترام، وما يجده من توجيهات مناسبة، وضعف تهيئة بعض المدارس، وقولة الوسائل التعليمية ، أو عدم توفيرها ِِخْ بعضها.

النتائج المتعلقة بالسؤال الرابع والذي ينص على التالي: هل توجد فروق ذات دلالة إحصائية

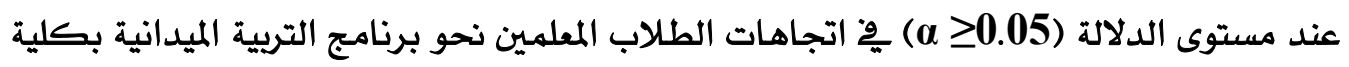
العلوم والآداب بشرورة ملتغير التقدير؟ للإجابة عن هذا السؤال تم استخراج المتوسطات الحسابية والانحرافات المعيارية لاستجابات أفراد العينة على الأداة، كما تم استخدام تحليل التباين الأحادي لاستخراج دلالة الفروق على الدرجة الكلية للأداة تبعًا لمتغير التقدير ، كما يوضحه الجدول رقم (9) ورقم (10). الجدول رقم (9) المتوسطات الحسابية والانحرافات المعيارية لاتجاهات الطلاب المعلمين نحو برنامج التربية الميدانية بكلية العلوم والآداب بشرورة تبعا لمتغير التقدير.

\begin{tabular}{|c|c|c|c|c|}
\hline الانحراف المعياري & & & المستويات & المتغير المستقل \\
\hline 0.00000 & 3.9000 & 2 & مقبول & \multirow{4}{*}{ التقدير } \\
\hline 0.46179 & 3.7269 & 26 & جيد & \\
\hline 0.64903 & 3.7597 & 31 & جيد جداً & \\
\hline 0.55805 & 3.5917 & 6 & مهتاز & \\
\hline
\end{tabular}

يلاحظ من الجدول (9) وجود فروق ظاهرية بين المتوسطات الحسابية وفقا لمتفير التقدير، وللكشف عن دلالة الفروق بين المتوسطات استخدم تحليل التباين الأحادي (ANOVA)، ويبين

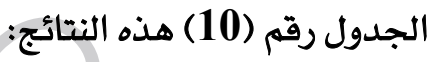
الجدول رقم (10) نتائج تحليل التباين الأحادي للكشف عن دلالة الفروق پِ اتجاهات الطلاب المعلمـين نحو برنامجا التربية الميدانية بكلية العلوم والآداب بشرورة تبعا لمتغير التقدير.

\begin{tabular}{|c|c|c|c|c|c|c|c|}
\hline الاستتتاج & مستوى الدلالة & قيمة & متوسط المربعات & درجات & مجموع المربعات & & \\
\hline \multirow{3}{*}{ غير دالة عند } & \multirow[t]{3}{*}{0.892} & \multirow[t]{3}{*}{0.206} & 0.066 & 3 & 0.198 & بين المجهموعات & \multirow{3}{*}{ الكلية } \\
\hline & & & 0.320 & 61 & 19.525 & المجهوعات & \\
\hline & & & & 64 & 19.724 & المجموع & \\
\hline
\end{tabular}

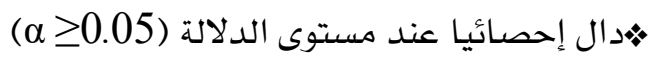




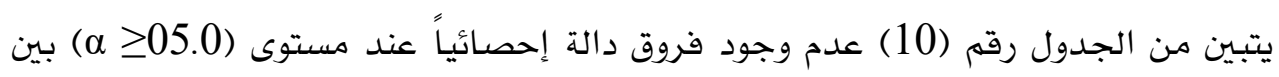
المتوسطات الخاصة بح مجال اتجاهات الطالبات، والطلاب المعلمـين نحو التربية الميدانية ونشاطاتها تعزى لاختلاف متغير التقدير، فكانت قيمة ف (0.206)، ومستوى دلالتها (0.892) وهي أكبر من (0.05)، ويعزو الباحث هذه النتيجة إلى أن التربية الميدانية تعتمد على الممارسة بشكل كبير أكثر من اعتهادها على المعلومات، ويتوافق هذا مع دراسة خوالدة (2010)

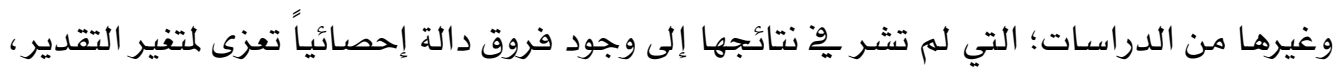
خلافاً لمتغيرات أخرى.

التوصيات پِّ ضوء ما تم التوصل إليه من نتائج يهكن التقدم بالتوصيات التالية: 1- الاهتهمام باتجاهـات الطالبات، والطلاب المعلميـن نحو التربية الميدانية.، 2- العهل على توسيع هجالات، ووسائل الحوار، والنقاش، والتدريب، والتفاعل، والتواصل وِ التربية الميدانية، وإنـراك كل الأطراف المعنية ِِّ ذلك هن: الطالب المعلم، المشرف التربوي أو الأكاديهي، المعلم المتعاون، قائد المدرسة، المتخصصسن وأسـاتذة طرائق التدريس، الأمر الذي ينعكس إيجاباً على اتجاهـات الطلاب المعلمـين نحو التربية الميدانية العناية باختيار المشـرفين ومدارس التدريب، والمعلمـين المتعاونين؛ الذين يقومون بالإشـراف على تدريب الطلاب المعلمـين، وعقد اللقاءات، والندوات معهم لتطوير أدائهم يخّاء الإشراف على التدريب. المقترحات وِّ ضوء النتائج والتوصيات السابقة فإن الباحث يقترح إجراء بعض الدراسـات؛ التي يمكن أن تسهم يخ النهوض بالتربية الميدانية، ومنها: مقارنة بين واقع التربية الميدانية، ونشاطاتها ِخ جامعات مختلفة، واتجاهات الطلاب

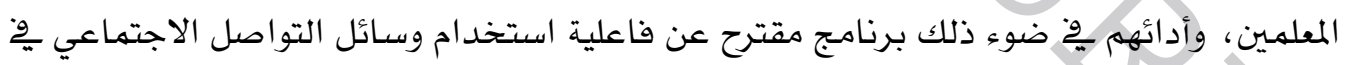
تتمية الأداء التدريسي للطلاب المعلمين برنامـج مقترح عن فاعلية ورش التدريب ِوْ تتمية الأداء التدريسي للطلاب المعلمـين. 
1. الأدغم، رضا أحمد حافظ (2003). تطوير برنامج إعداد معلمي اللغة العربية ِّ ضوء متطلبات العصر، كلية التربية، جامعة المنصورة.، أبو لبدة، عبد الله علي، والخليلي، خليل يوسف، وأبو زينة، فريد كامل (1996). المرشد مِ التدريس. دبي، دار القله.

3. أبو صالح، محمد (2004) الطرق الاحصائية. عمان: دار اليازوري. 4. جامعة القدس المفتوحة (1992). علم النفس التربوي. القدس: منشورات جامعة القدس المفتوحة.

5. الزهراني، محسن جابر (2013). دور مواقع التواصل الاجتماعي مِّحل المشكلات التي تواجه طلاب التربية العملية واتجاهاتهم نحوها ، رسالة ماجستير غير منشورة ، كلية التربية، جامعة أم القرى. مكة المكرمة.

6. الزيود ، أسـامة محمد فياض (2008) فاعلية استخدام/أسلوب التدريس المصفر ِِّ تتمية مهارات بعض كفايات التدريس لدى معلمي الطلبة ذوي صعوبات التعلم، دراسة دكتوراه غير منشورة، كلية الدراسـات العليا ، جامعة أحمدرمان الإسـلامية. 7. حلس، داود درويش (2011). مشروع تطوير برنامج التربية العملية التربية الميدانية العملية ِِ الجامعات الفلسطينية (مفهومها - أهميتها - أهدافها - أبعادها - مراحلها). كلية التربية- الجامعة الإسـامية- عزة. 8. حهص، محسن محهد وعلي، سهير (1419هـ). المرجع الشامل يخ التربية الميدانية - نظريات - تطبيقات. الرياض:دار الخريجي.

9. الخطيب، علم الدين (2004). دراسة تقويمية لأداء المشرف الخارجي ِِّ برنامج التربية العملية مِّ2 كلية التربية. جامعة الكويت. المجلة التربوية، 18 (70) 160- 195. 10. خوالدة، مصطفى، واحميدة، فتحي، والحجازي، فتحي (2010). مشكلات التربية العملية التي تواجه الطلبة المعلمين پخ تخصص تريية طفل پْ كلية الملكة رانيا للطفولة بالجامعة الهاشمية، مجلة جامعة دمشق للعلوم التربوية والنفسية 26 (3) 737- 781. 11. شـاهين، عبدالرحمن (2015). اتجاهات طلاب الجامعة الاسلامية بالمدينة المنورة نحو مقرد طرق التدريس والتربية العملية ومهنة التعليم مِّ ضوء بعض المتغيرات. مجلة العلوم التربوية، 1 402 - 356 (4) 
12. شـاهـين، محمدعبدالفتاح (2007)، تقويم برنامج التربية العملية ِِّْ جامعة القدس المفتوحة، مجلة جامعة الأقصى، غزة، 11 (1) 171 - 208.

13. شحادة، فواز والبوني، عبد الرزاق (2016) التدريب الميداني ودوره ِِّْ تغيحر اتجاهات طلبة كلية التربية بوادي الدواسر نحو مهنة التدريس. مجلة العلوم التربوية، جامعة السودان للعلوم

$$
\text { والتكنولوجيا } 3 \text { (17) 65 - }
$$

14. الشهري، محمد هـادي (2012). فاعلية برنامج قائم على استخدام نشاطات القراءة هِّ تتمية مهارات الفهم القرائي والاتجاه نحوها لدى تلاميذ الصف السادس الابتدائي، أطروحة دكتوراه غير منشورة، كلية التربية- جامعة أم القرى- مكة المكرمة.

15. العبادي، حامد مبارك (2004). مشككلات التربية العملية كما يراها الطلبة المعلمون هِ تخصص معلم الصف وعلاقتها باتجاهاتهم نحو مهنة التدريس، مجلة دراسـات العلوم التربوية، جامعة اليرموك، عمان 31 (2) 242- 252. 16. عبد الرحهن، عفيف وقطامي، يوسف وقطامي، نايفة (1992) اتجاهات الطلبة الدارسين مِّ كلية تأهيل المعلمين العالية نحو مهنه التدريس، مجلة مؤته للبحوث والدراسـات، الأردن $.225=189$ (3) 7

17. العمايرة، محمد حسن (2003) مشككلات التربية العملية كما يراها طلبة الفصل الثامن هِ كلية العلوم التربوية الجامعية ، الأونروا : مجلة العلوم التربوية (4) 194- 159. 18. عمر، عاصهم عمر إبراهيم (2013) برنامج مقترح هِ التربية العملية قائم على شبكات التواصل الاجتماعي 2خ تتمية المفاهيم العلمية وعادات العقل لدى الطالبات معلمات رياض الأطفال، مجلة دراسـات عربية يخّ التربية وعلم النفس، مصر ، 1 (40)1930- 270. 19. عيسوي، عبدالرحمن (1981م) دراسات سيكولوجية. القاهرة: دار المعارف. 20. العيوني، صالح محمد، والفالح، ناصر بن عبدالرحهن (2002) دليل التربية الميدانية لكليات المعلمين بِّ المملكة العربية السعودية. وزارة المعارف. كلية المعلمـين.الرياض. 21. لجنة التربية العهلية (1437هـ) دليل التربية العملية، قسم التربية، كلية العلوم والآداب بشرورة، جامعة نجران، المملكة العريية السعودية، تم استرجاعه بتاريخ 1/2/ 1438ه على http://scashar.nu.edu.sa/564 الرابط: 22. مسعود ، كلير أنور (2001) " تتمية الاتجاهات الإيجابية نحو القراءة المصورة لدى أطفال ما قبل المدرسة"، أطروحة دكتوراه غير منشورة، قسم رياض الأطفال والتعليم الابتدائي، معهد الدراسـات والبحوث التربوية ، جامعة القاهرة: القاهرة. 
23. ناصر، حسام توفيق، (1999) العلاقة بين الاتجاهات نحو الرياضيات والتحصيل الدراسي فيها لدى طلبة الصف العاشر بِ محافظة طولكرم، رسالة ماجستير غير منشورة، جامعة النجاح الوطنية ، نابلس: فلسطين.

24. نصر الله، توفيق محمد (1988) اتجاهات تلاميذ المرحلة الثانوية نحو القراءة وعلاقتها بالتحصيل الدراسي يخ اللغة العربية، رسالة ماجستير غير منثورة، كلية التربية، جامعة أم

$$
\text { القرى: مكة المكرمة. }
$$

25. نور الدين، مازن (2009) الكفايات الإشرافية اللازمة لمدير المدرسة ِّ2 إشرافه على الطالب المعلم، اليوم الدراسي (التدريب الميداني بين أداء الطالب المعلم وتوجيهات المشرف التربوي والإدارة المدرسية) كلية التربية- الجامعة الإسـلامية، غزة، لمئ، 2 مايو. 


\section{References}

- Beck, Clive ,2002 (: Components of a good practicum placement, Student Teacher Perceptions http://www.findarticle-com/p/articles /miqa360lis 200204/ai-nqou9695/print.

- Cheung-On, T., \& Yin-Wah, P. (2001). The changing roles of practicum/ field experience tutors, paper presentsd at the symposium of field experience, hongkong institute of education, (On line): Available at: http://www.ied.edu.hk/celts/symposium/docfull

- G.L.Arora ,2006 (: school Experience programme and quality in Teacher Education . http://www.net-in . org/glarora . htm

- Kyriacou, chris \& Stephens Paul ,1999: Student Teachers Concerns During Teaching Practice . Education \& Research in Education 13 (1) $18-31$.

- Munoz, C.,\& Towner, T. (2009). Opening Facebook: How toUse Facebook in the College Classroom. Paper presented at the 2009Society for Information Technology and Teacher Education conference, Charleston, South Carolina.

- Sandholtz, J. and Shannon, H. (2000). Professional development school trade-offs In teacher preparation and renewal. Teacher Education Quarterly, 27 (1) 7-27.

- Srafard , M, (1995) The Pre - student teaching practicum: Don't leaving it to charee Education: America.

- Hockly, N. (2000). Modeling and cognitive apprenticeship in teacher education. ELT Journal, 54 (2) 118-125.

- Walelign, T. and Fantahun, M. (2006). Assessment on problems of the new pre-service teachers training program in Jimma University, Ethiopian Journal of Education and science, 2 (2), 63-72. 
مجلة جدارا للدراسات والبحوث
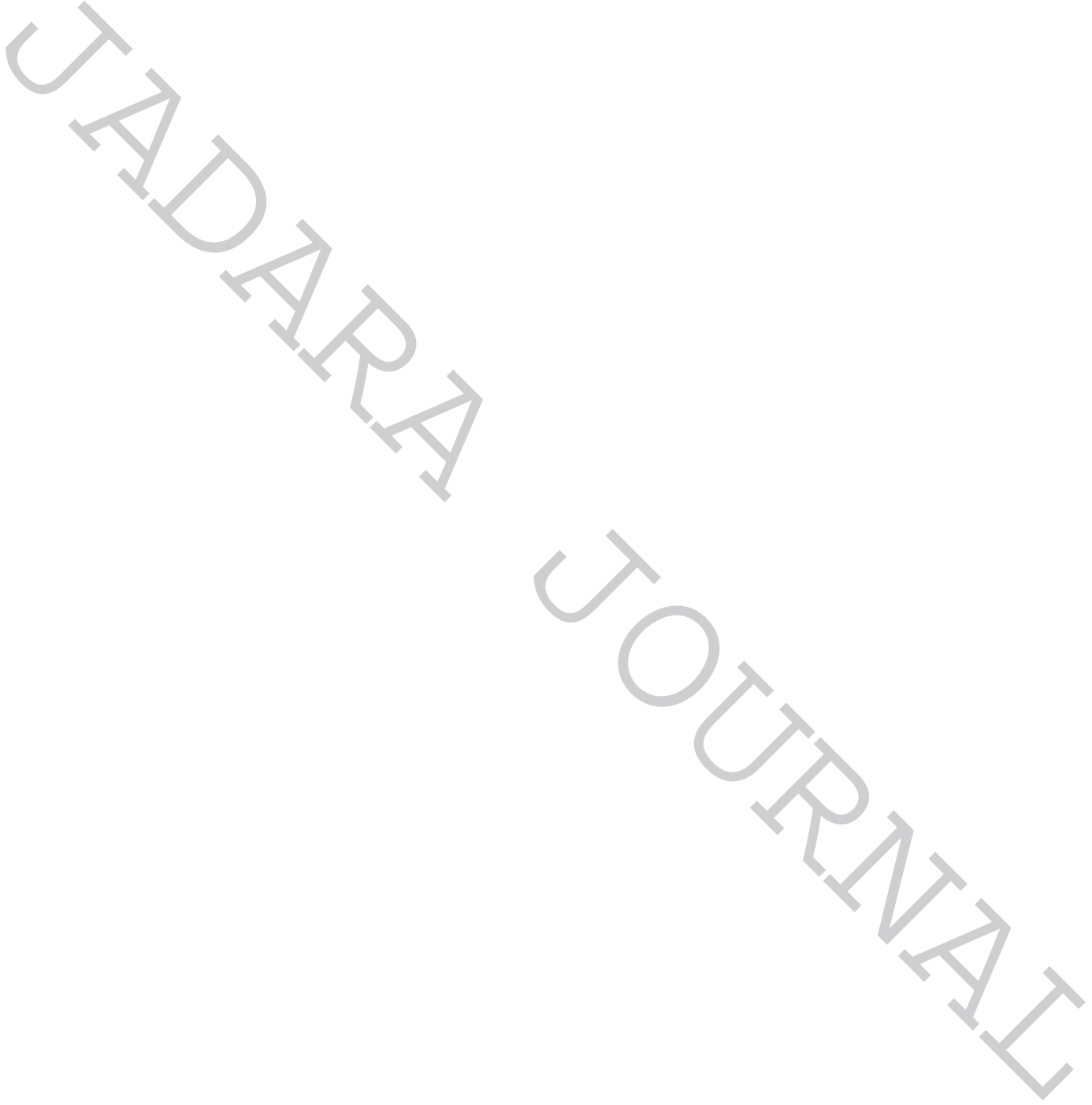